\title{
The Influence of Wives' and Husbands' Education Levels On Contraceptive Method Choice in Nepal, 1996-2006
}

\section{By Bina Gubhaju}

Bina Gubhaju is research associate, Social Policy Research Centre, University of New South Wales, Sydney, Australia.
CONTEXT: The association between education level and fertility, contraceptive behavior and method choice has been extensively researched, but little is known about how the education differential between husbands and wives in Nepal may influence the choice of specific methods.

METHODS: Data collected from currently married, nonpregnant women aged 15-49 in the Nepal Demographic and Health Surveys of 1996, 2001 and 2006 were analyzed to identify shifts in the education levels of husbands and wives and the influence of those shifts on couples'current contraceptive method use over the past decade. Multinomial logistic regression models assessed associations between method choice and each partner's education level, the education differential between partners and a combined education measure.

RESULTS: Although the wife's education level was associated with the type of method used by the couple, the husband's education level had more influence on the use of male sterilization and condoms. For example, men with any secondary or higher education were more likely than those with none to rely on either of these methods (relative risk ratios, 1.6-2.1). Furthermore, couples in which the husband had at least six more years of education than the wife also showed increased reliance on male sterilization or condoms (1.6-1.8). Differences in the use of any method of family planning by education level have narrowed considerably in the past decade, although differentials remain in the use of some methods.

CONCLUSION: A better understanding of how wives' and husbands' relative educational attainment affects decisions on their contraceptive choices is needed, particularly when both education levels and contraceptive use are increasing. International Perspectives on Sexual and Reproductive Health, 2009, 35(4):176-185
Over the past three decades, substantial changes have occurred in fertility, family planning and contraceptive choice in Nepal. In the mid-1970s, fertility peaked at six births per woman, and only $3 \%$ of married women were using any form of modern birth control. ${ }^{1}$ Fertility declined to 4.1 births per woman by 2001, and to 3.1 by 2006 . Moreover, 26\% of married women were using a modern contraceptive method by 1996 , and this proportion rose to $44 \%$ by 2006 . $^{1}$

There have also been significant shifts in the contraceptive method mix in Nepal. When the country began its family planning program in 1968, sterilization-both male and female-was emphasized by the government in an effort to reduce the fertility rate in the largely rural and illiterate population. Male sterilization was the predominant method in the early years of the program, but it was soon replaced by female sterilization. ${ }^{2}$ Although the latter has continued to be the most common method, the use of reversible methods has gradually increased. Injectable use, in particular, has increased steadily since 1991, and rose sharply between 1996 and 2001. Use of the pill and condoms has also increased since 2001.

Most family planning research in Nepal has focused on the dynamics of contraceptive use and nonuse, ${ }^{3-9}$ in part because overall use remains low and unmet need for family planning is high. The dominant goal among policymakers has been to reduce fertility levels by increasing contraceptive prevalence. Much less attention has been given to method choice, although a few recent studies have explored this issue. ${ }^{8,10-13}$ One study examined factors that influence the use of reversible versus permanent methods of birth control in the Chitwan district of Nepal. ${ }^{8}$ Another examined joint husband-wife involvement in contraceptive decision making in two rural population clusters; it found that unequal power relationships led to the husband's domination in decisions regarding whether to use contraceptives, which method to choose and whether to continue use. ${ }^{11}$

A study that used data from the 2001 Nepal Demographic and Health Survey (DHS) examined men's contraceptive choices and found that the number and sex of their children were important factors in men's use of permanent methods. ${ }^{13}$ Another study based on the same survey assessed the choices made by women, and emphasized that the education levels of the wife and the husband influenced which method a couple used. ${ }^{12}$ Although a higher level of education among women was associated with use of hormonal methods and condoms, women's education was not associated with whether their partner was sterilized. In contrast, a higher level of education among men was strongly associated with the use of con- 
doms and reliance on male sterilization.

According to descriptive data from the 2006 Nepal DHS, use of male sterilization was lowest among couples in which the woman had any secondary or higher education and was highest among couples in which the husband had the same amount. ${ }^{2}$ This raises important, unexplored questions about the couple-level dynamics that influence the relationship between the education levels of husbands and wives and their choices of family planning methods. For example, how does method choice vary if both the husband and the wife are uneducated, if both are educated, if the husband is more educated than the wife or vice versa? Previous studies have explored the independent and additive effects of partners' education levels on family planning, $8,10-13$ however, few have explored how the education levels of both partners may combine to influence the types of contraceptive methods used by couples.

This study expands on previous studies in Nepal by providing a more in-depth examination of the link between husbands' and wives' education levels and method choice. Using the 1996, 2001 and 2006 Nepal DHS data, it also assesses how the influence of education-of the wife, the husband and both-on contraceptive use and method choice in Nepal has changed over the past decade.

\section{BACKGROUND}

The associations between women's education level and fertility, contraceptive use and method choice have been studied extensively. Higher education levels among women have consistently been associated with lower fertility and greater contraceptive use, although the exact mechanisms through which education is related to such outcomes have not been identified. . $^{\text {14-20 }}$

Previous studies have found that sterilization-male or female-was the most commonly used method among couples in which the woman had a low education level, particularly in South Asia, where government family planning programs tend to focus on poor, uneducated rural women. ${ }^{8,21-24}$ These studies showed that women with higher levels of education were more likely to rely on reversible methods than on permanent methods.

Because husbands play a major role in their wives' contraceptive decisions, the association between their education levels and couples' contraceptive use has also been examined. For example, Axinn emphasized that the popularity of vasectomy in rural areas in Nepal made it imperative to assess husbands' characteristics in the contraceptive decision-making framework: ${ }^{5}$ the use of other male-controlled methods, such as condoms and withdrawal, also depends on the cooperation of the husband. Chapagain further argued that Nepali husbands play a significant role in influencing their wives to use femalecontrolled methods. ${ }^{10}$ Moreover, according to a study using data from the Vietnam DHS, husbands' education level had an even greater influence on contraceptive use than did wives' education level. ${ }^{25}$ In two studies of Turkish couples, husbands' characteristics (including educa- tion) were strongly associated with the use of withdrawal. ${ }^{26,27}$ However, another Turkish study found no association between husbands' education and method choice after controlling for wives' education. ${ }^{28}$

Thus, research on the relationship between husbands' education and contraceptive use has been inconclusive, as studies have found varying effects of husbands' education on both use and method choice. Nonetheless, the potential influence of husbands' education on their wives' contraceptive behavior, whether through direct or mediating factors, has prompted researchers to consider the role of men in family planning and the relative influence of husbands and wives on contraceptive decision making. ${ }^{29-31}$

In most previous studies, regardless of whether authors analyzed women's data or couples' data, wives' and husbands' education levels have been considered separately in analytical models. Thus, the independent and additive effects of each partner's education on contraceptive behavior have been well assessed. However, the combined effects of husbands' and wives' education levels have not been investigated, particularly in the context of Nepal.

\section{METHODS}

\section{Data}

This analysis used 1996, 2001 and 2006 Nepal DHS data. 2,32,33 The sample was restricted to all currently married women who said they were not pregnant at the time of the survey; eligible respondents with missing values were excluded.* The final sample for the descriptive and bivariate analyses included 6,879 women in 1996, 7,423 women in 2001 and 7,591 women in 2006. The multivariate analyses included 6,691, 7,100 and 7,266 respondents for the three surveys, respectively.

\section{Variables}

The dependent variable is a five-category measure of the current contraceptive method used: none, female sterilization, male sterilization, hormonal or other methods (the pill, injectable, IUD, implant, foam or jelly), or condoms. Users of traditional methods (periodic abstinence, withdrawal or other) were included in the descriptive results, but were excluded from the multivariate analysis.

The key independent variables are various measures of wives' and husbands' educational attainment (as reported by wives). First, partners' education levels were considered separately so that their independent associations with contraceptive use could be assessed; these continuous measures were recoded into a trichotomous variable (no education, any primary, or any secondary or higher). Second, the difference in education between husbands and wives was determined and recoded into a three-category variable (wife and husband have the same level of education or the wife has more, husband has completed 1-5 more years of education or husband has completed at least six more

*The numbers of cases excluded because of missing values were 335, 164 and 28 for the 1996, 2001 and 2006 surveys, respectively. 
TABLE 1. Percentage distribution of currently married, nonpregnant women aged 15-49, by selected characteristics, according to survey year, Nepal

\begin{tabular}{|c|c|c|c|c|c|c|c|}
\hline Characteristic & 1996 & 2001 & 2006 & Characteristic & 1996 & 2001 & 2006 \\
\hline \multicolumn{4}{|l|}{ Current contraceptive use ${ }^{* * *}$} & \multicolumn{4}{|l|}{ No. of living sons** } \\
\hline None & 68.0 & 56.5 & 48.3 & 0 & 23.9 & 24.0 & 21.8 \\
\hline Female sterilization & 13.4 & 16.5 & 19.5 & $\geq 1$ & 76.1 & 76.0 & 78.2 \\
\hline Male sterilization & 6.1 & 7.0 & 6.8 & & & & \\
\hline Hormonal method/other† & 7.5 & 12.4 & 16.3 & Wife's work status*** & & & \\
\hline Condoms & 2.2 & 3.2 & 5.2 & Not working & 16.1 & 16.1 & 16.1 \\
\hline \multirow[t]{2}{*}{ Traditionalf } & 2.8 & 4.4 & 4.0 & Agriculture worker & 76.0 & 76.3 & 72.4 \\
\hline & & & & Nonagriculture worker & 7.9 & 7.6 & 11.4 \\
\hline \multicolumn{8}{|l|}{ Wife's education**** } \\
\hline None & 79.1 & 71.6 & 62.5 & \multicolumn{4}{|c|}{ Wife knows of family planning methods*** } \\
\hline Any primary & 11.2 & 14.9 & 16.9 & $0-4$ & 24.7 & 7.3 & 4.7 \\
\hline \multirow[t]{2}{*}{ Any secondary/higher } & 9.6 & 13.5 & 20.6 & $5-7$ & 49.9 & 52.8 & 52.7 \\
\hline & & & & $\geq 8$ & 25.4 & 39.9 & 42.6 \\
\hline \multicolumn{8}{|l|}{ Husband's education*** } \\
\hline None & 42.5 & 35.3 & 25.5 & \multicolumn{4}{|c|}{ Wife discusses family planning with husband ${ }^{* * *}$} \\
\hline Any primary & 23.3 & 25.7 & 27.9 & Never & 57.2 & 58.7 & 57.5 \\
\hline \multirow[t]{2}{*}{ Any secondary/higher } & 34.2 & 39.1 & 46.6 & Sometimes & 33.4 & 28.7 & 30.7 \\
\hline & & & & Often & 9.4 & 12.6 & 11.9 \\
\hline \multicolumn{8}{|c|}{ Education difference between spouses*** } \\
\hline Same level/wife has more & 47.0 & 42.7 & 37.0 & \multicolumn{4}{|c|}{ Husband approves of family planning*** } \\
\hline Husband has 1-5 more yrs. & 30.4 & 34.4 & 40.0 & Yes & 74.0 & 79.4 & 82.6 \\
\hline \multirow[t]{2}{*}{ Husband has $\geq 6$ more yrs. } & 22.6 & 22.9 & 23.0 & No & 13.0 & 10.9 & 10.0 \\
\hline & & & & Don't know & 13.0 & 9.7 & 7.4 \\
\hline \multicolumn{8}{|l|}{ Combined education*** } \\
\hline Both have none & 40.6 & 33.1 & 23.4 & Urban residence**** & & & \\
\hline Both have any primary & 2.7 & 4.3 & 5.3 & Yes & 8.6 & 9.8 & 14.9 \\
\hline Both have any secondary/higher & 8.9 & 12.3 & 18.2 & No & 91.4 & 90.2 & 85.1 \\
\hline Wife has none, husband has any primary & 20.1 & 20.4 & 20.7 & & & & \\
\hline \multicolumn{4}{|l|}{ Wife has none, husband has any } & \multicolumn{4}{|l|}{ Region of residence**** } \\
\hline secondary/higher & 18.4 & 18.1 & 18.4 & Eastern & 23.4 & 24.1 & 21.4 \\
\hline \multicolumn{4}{|l|}{ Wife has any primary, husband has any } & Central & 32.9 & 31.7 & 32.8 \\
\hline secondary/higher & 6.9 & 8.7 & 10.0 & Western & 19.6 & 20.7 & 19.5 \\
\hline \multirow[t]{2}{*}{ Wife has more } & 2.5 & 3.1 & 4.0 & Midwestern & 14.4 & 13.8 & 11.7 \\
\hline & & & & Far western & 9.7 & 9.7 & 14.5 \\
\hline \multicolumn{8}{|l|}{ Wife's age ${ }^{* * *}$} \\
\hline $15-24$ & 29.9 & 28.3 & 26.2 & Wealth index $* * *$ & & & \\
\hline $25-34$ & 36.1 & 36.2 & 35.7 & Poorest & 21.4 & 21.7 & 18.5 \\
\hline \multirow[t]{2}{*}{$\geq 35$} & 33.9 & 35.4 & 38.0 & Poor & 18.6 & 19.2 & 19.6 \\
\hline & & & & Middle & 20.5 & 18.7 & 21.1 \\
\hline \multicolumn{4}{|l|}{ Age difference between spouses*** } & Rich & 19.9 & 20.0 & 20.0 \\
\hline Same age/wife is older & 14.5 & 13.0 & 14.0 & Richest & 19.6 & 20.3 & 20.7 \\
\hline Husband is $1-5$ yrs.older & 51.5 & 55.5 & 56.5 & & & & \\
\hline Husband is $6-10$ yrs. older & 23.1 & 22.5 & 21.7 & Total & 100.0 & 100.0 & 100.0 \\
\hline Husband is $>10$ yrs. older & 11.0 & 9.0 & 7.9 & & & & \\
\hline \multicolumn{8}{|l|}{ No. of living children $* * *$} \\
\hline $0-1$ & 26.2 & 24.6 & 24.4 & & & & \\
\hline $2-3$ & 38.9 & 40.6 & 46.0 & & & & \\
\hline$\geq 4$ & 35.0 & 34.7 & 29.6 & & & & \\
\hline
\end{tabular}

${ }^{* *} p<.01 .{ }^{* * *} p<.001$. Includes the pill, injectable, IUD and implant, as well as a few cases of foam or jelly use. IIncludes periodic abstinence, withdrawal and other traditional methods. Note: Percentages are weighted and may not total 100.0 because of rounding.

years). Third, a seven-category variable for spouses' combined education levels was constructed: neither has any education, both have some primary, both have some secondary or higher, wife has no education and husband has some primary, wife has no education and husband has some secondary or higher, wife has some primary and husband has some secondary or higher, or wife has completed more education than her husband.

Other independent variables that have been shown to be related to contraceptive adoption and method choice

*Household wealth index was calculated from a household's ownership of durable goods (e.g., television, car, bicycle) and dwelling characteristics (e.g., flooring material, source of drinking water, toilet facilities) (source: Rutstein S and Johnson K, The DHS Wealth Index, Calverton, MD, USA:Macro International, 2004). were also included in the analytical models: ${ }^{22}$ wife's age (15-24, 25-34, or 35 or older), age difference between partners (same age or wife is older, husband is $1-5$ years older, husband is 6-10 years older or husband is more than 10 years older), number of living children $(0-1,2-3$, or four or more), number of living sons (none, or one or more), wife's work status (not working, agricultural worker or nonagricultural worker), wife's knowledge of family planning methods $(0-4,5-7$, or eight or more), whether wife has discussed family planning with husband (never, sometimes or often), whether wife thinks her husband approves of family planning (yes, no or don't know), urban residence (yes or no), region of residence (eastern, central, western, midwestern or far western) and wealth index by quintile (poorest, poor, middle, rich or richest).* 


\begin{tabular}{|c|c|c|c|c|c|c|c|c|c|c|c|c|c|c|c|c|c|c|c|c|c|c|}
\hline \multirow[t]{2}{*}{ Characteristic } & \multicolumn{3}{|c|}{$\begin{array}{l}\text { Any } \\
\text { method }\end{array}$} & \multicolumn{3}{|c|}{$\begin{array}{l}\text { Female } \\
\text { sterilization }\end{array}$} & \multicolumn{3}{|c|}{\begin{tabular}{|l} 
Male \\
sterilization
\end{tabular}} & \multicolumn{3}{|c|}{ Hormonal } & \multicolumn{3}{|c|}{ Condoms } & \multicolumn{3}{|c|}{ Traditional } & \multicolumn{3}{|c|}{ None } & \multirow[t]{2}{*}{ Total } \\
\hline & 1996 & 2001 & 2006 & 1996 & 2001 & 2006 & 1996 & 2001 & 2006 & 1996 & 2001 & 2006 & 1996 & 2001 & 12006 & 1996 & 2001 & 2006 & 1996 & 2001 & 2006 & \\
\hline \multicolumn{23}{|l|}{ Wife's education } \\
\hline None & 29.6 & 40.2 & 52.6 & 13.4 & 17.9 & 24.6 & 6.1 & 6.4 & 7.5 & 6.4 & 10.9 & 15.1 & 1.5 & 1.7 & 2.5 & 2.1 & 3.4 & 3.0 & 70.4 & 59.8 & 47.4 & 100.0 \\
\hline Any primary & 34.6 & 46.3 & 49.6 & 14.7 & 13.4 & 13.5 & 5.9 & 9.7 & 7.1 & 8.8 & 14.8 & 18.5 & 1.6 & 3.9 & 6.6 & 3.5 & 4.6 & 3.9 & 65.4 & 53.7 & 50.4 & 100.0 \\
\hline Any secondary/higher & 48.3 & 57.5 & 50.8 & 11.5 & 12.4 & 8.8 & 5.6 & 7.1 & 4.7 & 14.4 & 18.0 & 18.1 & 9.2 & 10.6 & 12.1 & 7.5 & 9.5 & 7.1 & 51.7 & 42.5 & 49.2 & 100.0 \\
\hline \multicolumn{23}{|l|}{ Husband's education } \\
\hline None & 25.3 & 36.7 & 50.3 & 12.7 & 17.9 & 25.4 & 4.5 & 4.2 & 5.3 & 5.3 & 9.9 & 15.3 & 0.9 & 1.0 & 1.8 & 1.8 & 3.7 & 2.6 & 74.7 & 63.4 & 49.7 & 100.0 \\
\hline Any primary & 31.9 & 43.5 & 50.4 & 13.7 & 15.9 & 20.5 & 7.3 & 8.3 & 6.4 & 7.2 & 13.7 & 17.5 & 1.6 & 2.4 & 3.1 & 2.1 & 3.2 & 2.9 & 68.1 & 56.5 & 49.6 & 100.0 \\
\hline Any secondary/higher & 40.2 & 49.6 & 53.3 & 14.0 & 15.5 & 15.6 & 7.1 & 8.6 & 8.0 & 10.4 & 13.8 & 16.1 & 4.3 & 5.8 & 8.3 & 4.4 & 5.8 & 5.4 & 59.8 & 50.4 & 46.7 & 100.0 \\
\hline \multicolumn{23}{|c|}{ Education difference between spouses } \\
\hline Same level/wife has more & 27.2 & 39.1 & 49.6 & 12.8 & 16.9 & 20.0 & 4.5 & 4.5 & 5.3 & 6.1 & 11.4 & 16.4 & 1.5 & 2.0 & 4.2 & 2.3 & 4.3 & 3.6 & 72.8 & 60.9 & 50.4 & 100.0 \\
\hline Husband has 1-5 more yrs. & 34.0 & 47.4 & 50.7 & 12.4 & 14.8 & 17.4 & 6.8 & 8.6 & 6.0 & 8.6 & 14.3 & 16.7 & 3.1 & 4.6 & 6.3 & 3.1 & 5.1 & 4.2 & 66.0 & 52.6 & 49.3 & 100.0 \\
\hline $\begin{array}{l}\text { Husband has } \geq 6 \text { more yrs. } \\
\text { Combined education }\end{array}$ & 39.0 & 45.7 & 57.1 & 15.8 & 18.2 & 22.2 & 8.2 & 9.2 & 10.7 & 8.9 & 11.3 & 15.3 & 2.6 & 3.4 & 4.7 & 3.5 & 3.6 & 4.2 & 61.0 & 54.3 & 42.9 & 100.0 \\
\hline Both have none & 24.9 & 36.4 & 50.4 & 12.5 & 18.1 & 26.4 & 4.5 & 4.1 & 5.3 & 5.2 & 9.6 & 14.6 & 0.9 & 1.0 & 1.4 & 1.8 & 3.6 & 2.6 & 75.1 & 63.7 & 49.6 & 100.0 \\
\hline $\begin{array}{l}\text { Both have any primary } \\
\text { Both have any secondary/ }\end{array}$ & 32.7 & 42.8 & 54.0 & 15.0 & 10.6 & 13.9 & 5.3 & 10.0 & 6.5 & 9.0 & 16.2 & 25.6 & 0.0 & 3.2 & 4.1 & 3.4 & 2.8 & 4.0 & 67.3 & 57.2 & 46.0 & 100.0 \\
\hline $\begin{array}{l}\text { higher } \\
\text { Wife has none, husband has }\end{array}$ & 48.3 & 58.4 & 52.1 & 10.8 & 11.8 & 8.8 & 5.4 & 7.4 & 5.0 & 14.1 & 17.7 & 17.4 & 9.7 & 11.2 & 13.0 & 8.2 & 10.2 & 7.9 & 51.7 & 41.7 & 47.9 & 100.0 \\
\hline $\begin{array}{l}\text { any primary } \\
\text { Wife has none, husband has }\end{array}$ & 31.3 & 43.4 & 50.7 & 13.5 & 17.0 & 23.2 & 7.6 & 8.1 & 6.8 & 6.5 & 12.8 & 15.4 & 1.7 & 2.0 & 2.5 & 2.0 & 3.4 & 2.8 & 68.7 & 56.6 & 49.4 & 100.0 \\
\hline $\begin{array}{l}\text { any secondary/higher } \\
\text { Wife has any primary, husban }\end{array}$ & 38.0 & 43.8 & 57.8 & 15.3 & 18.6 & 23.8 & 8.1 & 8.7 & 11.1 & 9.2 & 10.9 & 15.3 & 2.5 & 2.6 & 3.8 & 3.0 & 3.0 & 3.7 & 62.0 & 56.2 & 42.2 & 100.0 \\
\hline has any secondary/higher & 35.7 & 49.5 & 47.4 & 14.6 & 14.4 & 12.9 & 6.6 & 10.4 & 7.6 & 8.7 & 14.5 & 15.0 & 2.2 & 4.8 & 7.8 & 3.6 & 5.4 & 4.0 & 64.3 & 50.5 & 52.6 & 100.0 \\
\hline Wife has more & 37.6 & 43.3 & 43.9 & 16.2 & 16.1 & 11.8 & 5.1 & 5.3 & 3.5 & 12.1 & 15.8 & 20.7 & 1.9 & 2.4 & 5.9 & 2.4 & 3.7 & 1.9 & 62.4 & 56.7 & 56.1 & 100.0 \\
\hline
\end{tabular}

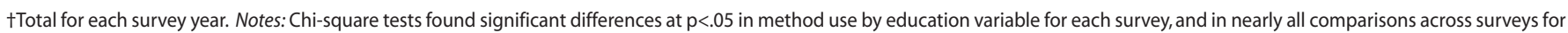
each method (the exception being the category "wife has more" in the combined education panel). Percentages are weighted and may not total 100.0 because of rounding.

Like parity, already having a son likely plays an important role in a couple's adoption of contraception, particularly in the use of permanent methods in South Asia. 8,13,34 Urban residence and region of residence were included to assess the effects of location; these variables also serve as proxy measures for access to and availability of family planning services and contraceptive methods. The central development region is the most developed economically, followed by the eastern and western regions.

\section{Analysis}

Descriptive characteristics of the samples are presented for the 1996, 2001 and 2006 surveys, as are percentage distributions of respondents by current contraceptive method according to education variables and survey year. Chisquare tests assessed differences in the distributions by background characteristics across survey years, as well as differences in method use by education variable for each survey and differences in use across surveys by each education category. Because of the categorical nature of the dependent variable, multinomial logistic regression analyses were conducted separately for each survey, with no method as the reference category for the dependent variable.

In Model 1, the education levels of wives and husbands were included as separate variables to assess the influence of each on method choice; the partner's education was controlled for in each case. Model 2 addressed the possible role of the difference in education between partners, and thus included the wife's education and education gap variables. Model 3 focused on the combined education variable. Because of the collinearity between wife's age and parity, the former was dropped from the multivariate models, which controlled for all other independent variables; the relative risk ratios were weighted and adjusted for survey data clustering.

\section{RESULTS}

\section{Sample Characteristics}

The percentage of women who reported that they were not currently using a contraceptive method decreased from $68 \%$ in 1996 to $48 \%$ in 2006 , which is equivalent to a $62 \%$ increase in contraceptive use over the decade (Table 1). * During the same period, use of female sterilization rose from $13 \%$ to $20 \%$, and use of hormonal methods doubled, from $8 \%$ to $16 \%$. Although the increase in hormonal methods between 1996 and 2001 was mainly the result of a sharp rise in the use of the injectable, pill use also increased between 2001 and 2006 (not shown separately). Condom use, which increased only slightly, from $2 \%$ in 1996 to $3 \%$ in 2001, reached $5 \%$ in 2006. The use of male sterilization remained level across the three surveys at $6-7 \%$, as did use of traditional methods at 3-4\%.

Substantial improvements in educational attainment in

*The characteristics of the respondents in this study are similar to those of the ever-married female population in the full data sets, with a few exceptions: In our sample from all three surveys, the proportion of women currently not using any method was $5 \%$ lower, and the proportions with 0-1 child and with at least one son were $3 \%$ lower. 


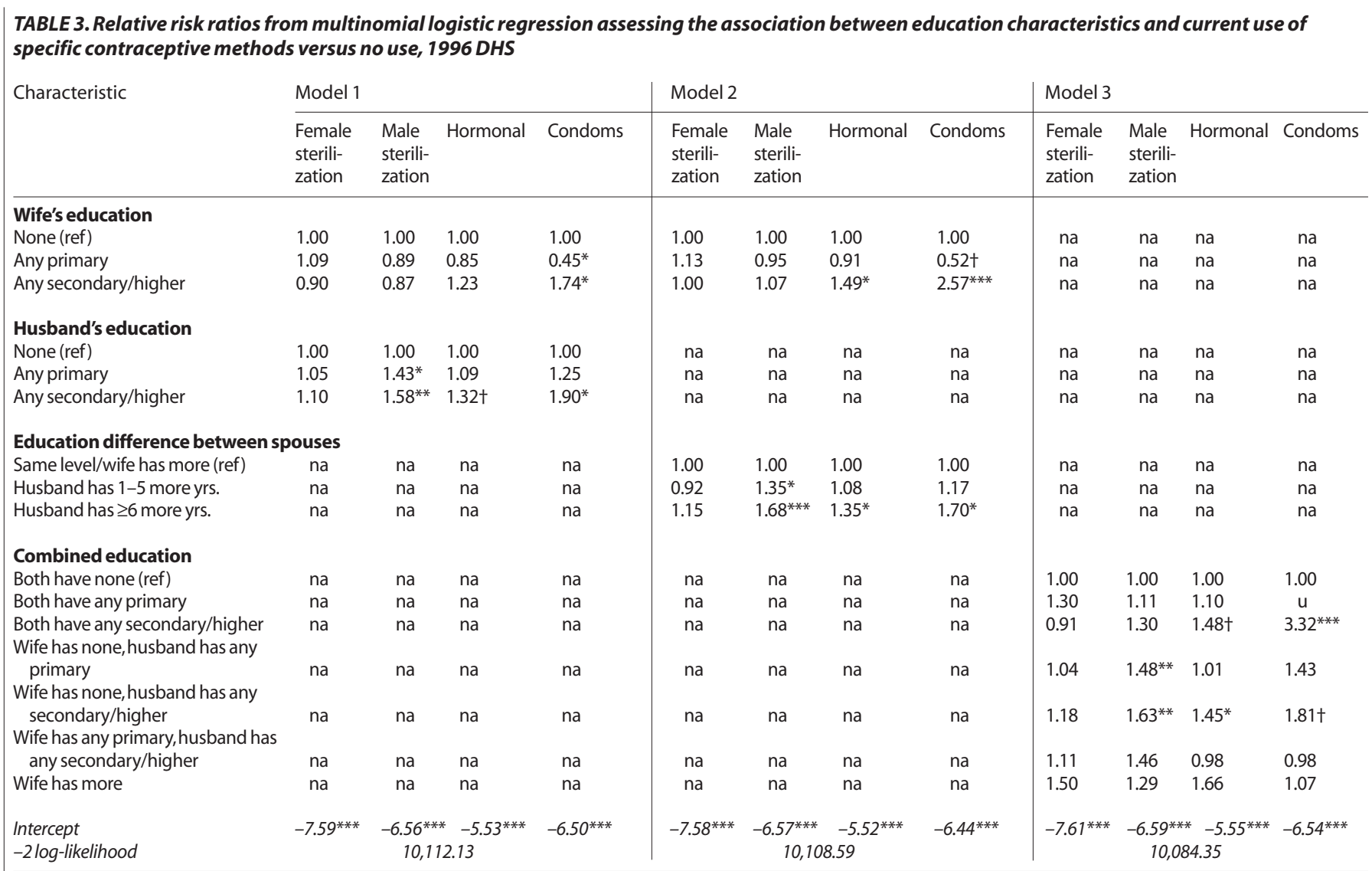

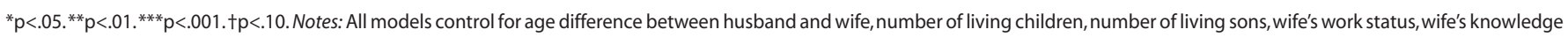

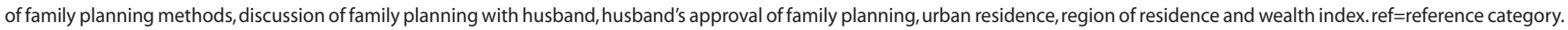
na=not applicable. $\mathrm{u}=$ unavailable because category has no cases.

Nepal have occurred over the past decade: The proportions of wives and husbands who have no education declined, and the proportions with any primary or any secondary or higher education rose. The increases in the proportions with any secondary or higher education were particularly marked, from $10 \%$ to $21 \%$ among women and from $34 \%$ to $47 \%$ among men.

The proportion of couples in which the wife had the same amount of education or more than her husband declined by 10 percentage points between 1996 and 2006, while the proportion in which the husband had 1-5 more years of education increased by the same amount. The percentage of couples in which the husband had at least six more years of education than the wife remained at $23 \%$. In 1996 , neither partner had any education in $41 \%$ of couples, a proportion that fell to $23 \%$ in 2006 . In contrast, the proportion of couples in which both had some secondary or higher education increased from $9 \%$ to $18 \%$ over the same period. However, the proportion of couples in which the wife had more education than the husband stayed level at 3-4\% over this period.

The distributions of respondents by age were similar in the three surveys, and the age difference between husbands and wives changed little: About half of the women had a husband who was 1-5 years older. One-quarter of respondents had no children or one child across the surveys, 39-46\% had two or three children, and 30-35\% had more than three children. More than three-quarters of women had at least one son in all three samples. Regarding employment, 16\% of women were not working in each survey year, and about three-quarters worked in the agricultural sector.

Women's knowledge of family planning methods grew over the decade: In 1996, 25\% knew of eight or more methods, and by 2006, 43\% knew of this many. However, the proportion of women who had never discussed family planning with their husband remained level at 57-59\%, and only 9-13\% said they discussed it frequently. Despite this lack of communication, the proportion of women who stated that their husband approved of family planning increased from 74\% in 1996 to $83 \%$ in 2006.

The proportion of respondents living in an urban area ranged from 9\% in 1996 to $15 \%$ in 2006. The proportion in each region changed little, with the highest percentages in the central, eastern and western regions. The wealth index was constructed using quintiles, so respondents were distributed equally across them for each survey.

\section{Bivariate Findings}

In both the 1996 and 2001 surveys, current use of any contraceptive method rose with wives' and husbands' education levels (Table 2, page 179). By 2006, however, there was almost no difference in contraceptive use by education 


\begin{tabular}{|c|c|c|c|c|c|c|c|c|c|c|c|c|}
\hline \multirow[t]{2}{*}{ Characteristic } & \multicolumn{4}{|l|}{ Model 1} & \multicolumn{4}{|l|}{ Model 2} & \multicolumn{4}{|l|}{ Model 3} \\
\hline & $\begin{array}{l}\text { Female } \\
\text { sterili- } \\
\text { zation }\end{array}$ & $\begin{array}{l}\text { Male } \\
\text { sterili- } \\
\text { zation }\end{array}$ & Hormonal & Condoms & $\begin{array}{l}\text { Female } \\
\text { sterili- } \\
\text { zation }\end{array}$ & $\begin{array}{l}\text { Male } \\
\text { sterili- } \\
\text { zation }\end{array}$ & Hormonal & Condoms & $\begin{array}{l}\text { Female } \\
\text { sterili- } \\
\text { zation }\end{array}$ & $\begin{array}{l}\text { Male } \\
\text { sterili- } \\
\text { zation }\end{array}$ & Hormonal & Condoms \\
\hline \multicolumn{13}{|l|}{ Wife's education } \\
\hline None (ref) & 1.00 & 1.00 & 1.00 & 1.00 & 1.00 & 1.00 & 1.00 & 1.00 & na & na & na & na \\
\hline Any primary & $0.78+$ & $1.35+$ & 1.19 & $1.53 \dagger$ & $0.77^{*}$ & $1.45^{*}$ & 1.15 & $1.62^{*}$ & na & na & na & na \\
\hline Any secondary/higher & 0.89 & 1.30 & $1.44^{*}$ & $3.23^{* * *}$ & 0.84 & $1.60^{*}$ & 1.24 & $3.85^{* * *}$ & na & na & na & na \\
\hline \multicolumn{13}{|l|}{ Husband's education } \\
\hline None (ref) & 1.00 & 1.00 & 1.00 & 1.00 & na & na & na & na & na & na & na & na \\
\hline Any primary & 0.96 & $1.97^{* * *}$ & $1.29 *$ & $1.71 \dagger$ & na & na & na & na & na & na & na & na \\
\hline Any secondary/higher & 0.89 & $2.06^{* * *}$ & 0.98 & $1.83^{*}$ & na & na & na & na & na & na & na & na \\
\hline \multicolumn{13}{|c|}{ Education difference between spouses } \\
\hline Same level/wife has more (ref) & na & na & na & na & 1.00 & 1.00 & 1.00 & 1.00 & na & na & na & na \\
\hline Husband has 1-5 more yrs. & na & na & na & na & 0.92 & $1.77^{* * *}$ & 1.11 & $1.61^{* *}$ & na & na & na & na \\
\hline Husband has $\geq 6$ more yrs. & na & na & na & na & 0.89 & $1.83^{* * *}$ & 0.86 & $1.58^{*}$ & na & na & na & na \\
\hline \multicolumn{13}{|l|}{ Combined education } \\
\hline Both have none (ref) & na & na & na & na & na & na & na & na & 1.00 & 1.00 & 1.00 & 1.00 \\
\hline Both have any primary & na & na & na & na & na & na & na & na & 0.71 & $3.19 * * *$ & $1.54^{*}$ & $2.21 \dagger$ \\
\hline $\begin{array}{l}\text { Both have any secondary/higher } \\
\text { Wife has none, husband has any }\end{array}$ & na & na & na & na & na & na & na & na & 0.77 & $2.77^{* * * *}$ & $1.44^{*}$ & $5.70^{* * *}$ \\
\hline $\begin{array}{l}\text { primary } \\
\text { Wife has none, husband has any }\end{array}$ & na & na & na & na & na & na & na & na & 0.97 & $1.95^{* * *}$ & $1.30^{*}$ & $1.79+$ \\
\hline $\begin{array}{l}\text { secondary/higher } \\
\text { Wife has any primary, husband has }\end{array}$ & na & na & na & na & na & na & na & na & 0.91 & $2.15^{* * *}$ & 1.00 & 1.54 \\
\hline any secondary/higher & na & na & na & na & na & na & na & na & $0.71^{*}$ & $2.56^{* * *}$ & 1.14 & $2.75^{* *}$ \\
\hline Wife has more & na & na & na & na & na & na & na & na & 0.94 & 1.48 & 1.46 & 1.82 \\
\hline $\begin{array}{l}\text { Intercept } \\
-2 \text { log-likelihood }\end{array}$ & $-8.16^{* * *}$ & $\begin{array}{r}-6.81^{* * *} \\
12,753\end{array}$ & $-4.19^{* * *}$ & $-7.02^{* * *}$ & $-8.15^{* * *}$ & $\begin{array}{r}-6.72^{* * *} \\
12,75\end{array}$ & ${ }^{-4.11^{* * *}}$ & $-6.94^{* * *}$ & $-8.15^{* * *}$ & $\begin{array}{r}-6.74^{* * *} \\
12,729\end{array}$ & $\begin{array}{l}*-4.21^{* * * *} \\
9.91\end{array}$ & $-7.03^{* * *}$ \\
\hline
\end{tabular}

level (50-53\% across all three levels for each spouse). Over the three surveys, use increased substantially among respondents with no education and among those with any primary education, but rose less among respondents with any secondary or higher education.

When the education difference between wives and husbands was considered, the proportion using any method in all three surveys was higher for couples in which the husband had more education than his wife than for couples in which the spouses had the same level of education or the wife had more schooling; in 1996 and 2006, for example, use was highest for couples in which the husband had at least six more years of education than the wife (39\% and $57 \%$, respectively). When the education levels of partners were combined, however, the picture was somewhat different. In 1996 and 2001, contraceptive use was highest when both partners had some secondary or higher education (48\% and 58\%, respectively), whereas in 2006, use was highest among couples in which the woman had no education and her husband had some secondary or higher education (58\%). In the 1996 and 2001 surveys, the proportion using any method was lowest among couples in which both spouses had no education (25\% and 36\%, respectively), while in 2006, use was lowest among women who had more education than their husband (44\%).

The type of contraceptive used by education level shift- ed between the survey periods. In 1996, 12-15\% of couples reported using female sterilization and $6 \%$ reported relying on male sterilization, regardless of the wife's level of education. By 2006, 25\% of women with no education relied on female sterilization and $8 \%$ on male sterilization, compared with $9 \%$ and $5 \%$, respectively, of women with some secondary or higher education.

In 1996, women with some secondary or higher education were more likely than those with no education to use a hormonal method (14\% vs. $6 \%$ ). This differential had narrowed by 2006, when 15-19\% of all women were using a hormonal method. Use of condoms and traditional methods rose with education in all three surveys.

Findings for the husband's education level and method choice were similar to those observed for women's education, with one exception: Husbands with any secondary or higher education were the most likely to use male sterilization in 2001 and 2006 (9\% and 8\%, respectively). Differences in method use by the education gap between partners were most prominent for male sterilization, whereas differences were marginal for the other methods. Couples in which the husband and wife had the same level of education or the wife had more were the least likely to use male sterilization (5\% in all three surveys), while couples in which the husband had at least six more years of education were the most likely to use this method ( $8-11 \%$ across the surveys). 
TABLE 5. Relative risk ratios from multinomial logistic regression assessing the association between education characteristics and current use of specific contraceptive methods versus no use, 2006 DHS

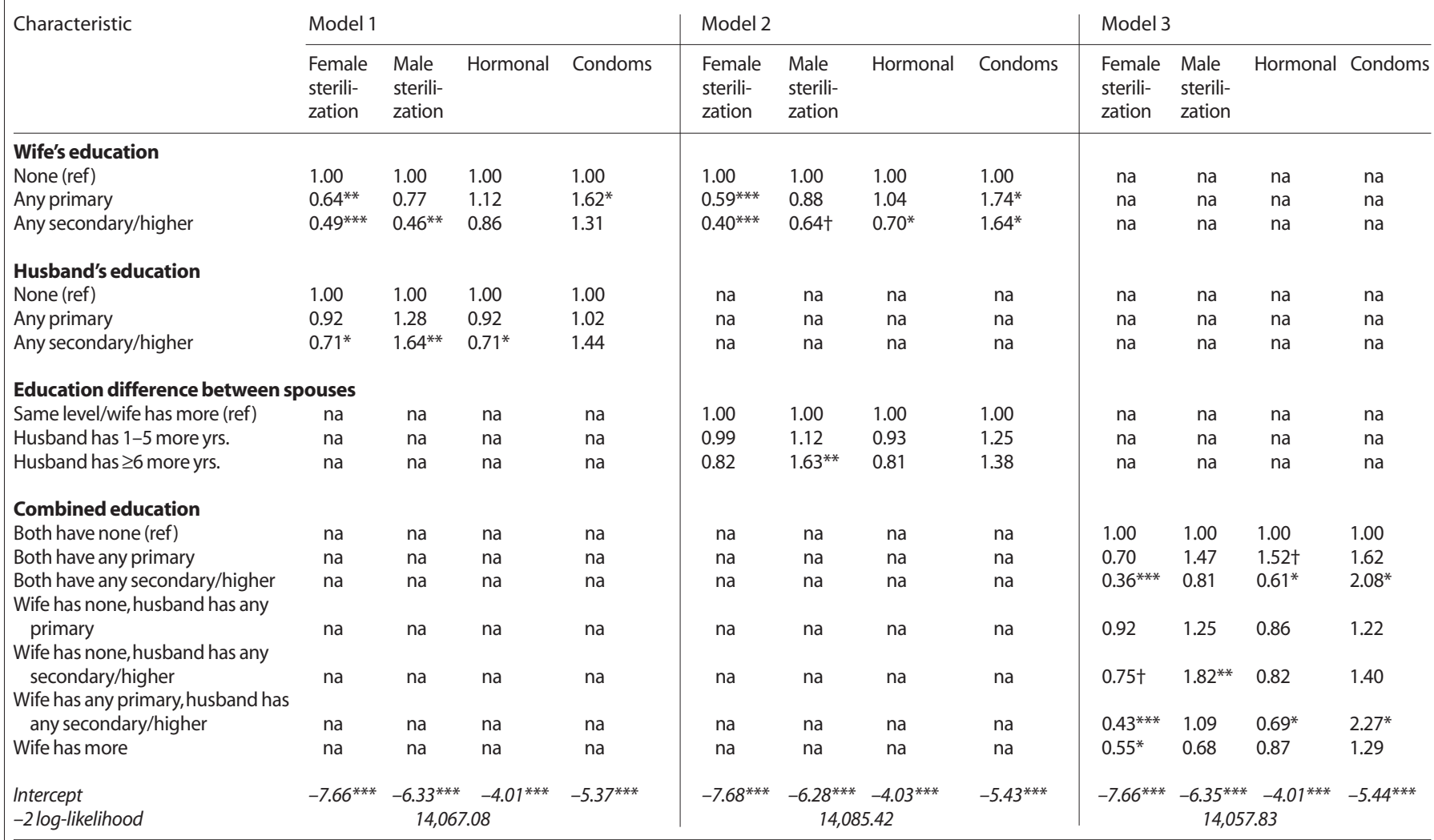

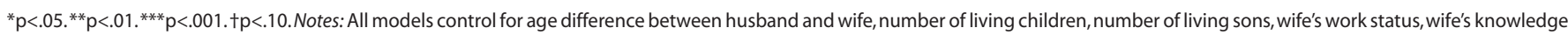

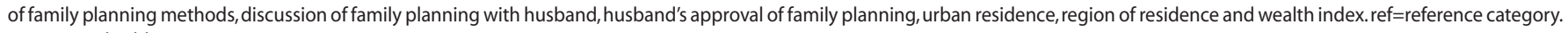
na $=$ not applicable.

The relationship between wives' and husbands' education levels was further scrutinized by examining method use differentials across the combined education categories. No striking differences were found for female sterilization across these categories in the 1996 and 2001 surveys. However, in 2006, couples in which both partners had any secondary or higher education were the least likely to use female sterilization (9\%), and couples in which both partners had no education were the most likely (26\%).

In 1996, couples in which both partners had any secondary or higher education were the most likely to use a hormonal method (14\%), but in 2006, such use was highest among couples in which both partners had any primary education (26\%). In all three surveys, couples in which both partners had any secondary or higher education were the most likely to use condoms or a traditional method.

\section{Multivariate Findings}

In the Model 1 analysis of the 1996 survey (Table 3, page 180), compared with women who had no education, those who had any primary education were significantly less likely to report using condoms than no method and those with any secondary or higher education were significantly more likely to do so (relative risk ratios, 0.5 and 1.7, respectively). Compared with women whose husband had no education, those whose husband had any primary education were more likely to use male sterilization (1.4), while those whose husband had any secondary or higher education were more likely to use this method or condoms (1.6 and 1.9 , respectively). In Model 2, couples in which the husband had more education than the wife had an increased likelihood of relying on male sterilization (1.4-1.7). When the husband had at least six more years of education than the wife, couples also were more likely to use a hormonal method or condoms ( 1.4 and 1.7, respectively).

Model 3 reinforced these results and also showed that, compared with couples in which neither partner had any education, couples in which the wife had no education and the husband had any primary or any secondary or higher education had a higher likelihood of relying on male sterilization (relative risk ratios, 1.5 and 1.6, respectively). In addition, the likelihood of using a hormonal method was elevated when the wife had no education and the husband had any secondary or higher education (1.5), as was the likelihood of relying on condoms when both partners had any secondary or higher education (3.3).

Results for the 2001 survey were similar (Table 4, page 181). Compared with women who had no education, those with any secondary or higher education were more likely to use a hormonal method or condoms (relative risk ratios, 1.4 and 3.2, respectively; Model 1). Couples in which the husband had any primary education were more likely to rely on 
male sterilization (2.0) or a hormonal method (1.3). Furthermore, couples' likelihood of relying on male sterilization or condoms was elevated (2.1 and 1.8, respectively) if the husband had any secondary or higher education. When the difference in spousal education was added (Model 2), husbands who had more education than their wife were more likely to report condom use or male sterilization (1.6-1.8) than were husbands who were less educated than or had the same level of education as their wife.

When the analysis of the 2001 data was limited to combined spousal education (Model 3), the likelihood of using female sterilization was lower when the wife had any primary education and the husband had secondary or higher education than when both spouses had no schooling (relative risk ratio, 0.7 ). In contrast, compared with couples who had no education, couples in most of the other combined categories (except that in which the wife had more education) were more likely to use male sterilization (2.0-3.2). The likelihood of using a hormonal method was increased among couples in which the wife had no education but the husband had any primary education, both had any secondary or higher education or both partners had any primary education (1.3-1.5). Finally, use of condoms was elevated among couples in which both partners had any secondary or higher education and among those in which the wife had any primary education and the husband had any secondary or higher education (5.7 and 2.8, respectively).

The pattern of associations between education level and method choice was different for the 2006 data (Table 5). Compared with women who had no education, those with any primary education were less likely to use female sterilization but more likely to use condoms (relative risk ratios, 0.6 and 1.6, respectively), while those with any secondary or higher education were less likely to rely on female or male sterilization ( 0.5 for each; Model 1 ). In addition, husbands with any secondary or higher education had a diminished likelihood of relying on female sterilization or hormonal methods ( 0.7 for each), but an elevated likelihood of using male sterilization (1.6). When education differences were added to the analysis (Model 2), husbands who had at least six more years of education than their wife were more likely to use male sterilization than those in the reference group (1.6).

When the analysis was limited to combined spousal education (Model 3), the likelihood of reporting female sterilization (compared with the likelihood among couples in which neither spouse had any education) was lower among couples in which both partners had any secondary or higher education, those in which the wife had any primary and the husband had any secondary or higher education, and those in which the wife had more education than the husband (relative risk ratios, 0.4-0.6). The likelihood of using male sterilization was elevated only among couples in which the wife had no education and the husband had any secondary or higher education (1.8). In contrast, the likelihood of using a hormonal method was diminished among couples in which both partners had any secondary or higher education, as well as among those in which the wife had any primary education and the husband had any secondary or higher education (0.6 and 0.7, respectively). Finally, as in the 2001 survey, the likelihood of using condoms in 2006 was more than doubled among couples in which both partners had any secondary or higher education and among those in which the wife had any primary and the husband had any secondary or higher education (2.1 and 2.3, respectively), compared with those in which neither partner had any schooling.

\section{DISCUSSION}

Previous studies have examined the influence of women's education, husbands' education and couples' characteristics on contraceptive behavior. ${ }^{14-18,25,29,31}$ The main contribution of this study is its inclusion of variables that measure the education difference between spouses and that capture the dynamics of partners' combined education levels to explore the links between contraceptive use and the relative education of wives and husbands. It also examined how the role of education in family planning use has changed over the past decade in Nepal.

This study focused on contraceptive method choice, because it is relevant to the recent fertility and family planning context in Nepal. The focus of government family planning policy has shifted from male and female sterilization to reversible spacing methods, particularly the injectable. As a result, the method mix has been changing in Nepal, with rising levels of injectable use and slight increases in pill and condom use.

The level of contraceptive use in Nepal has been growing over time, and one of the striking changes has been the shift in the profile of contraceptive users, particularly the increased use among women and men with lower education levels. In fact, use among women with secondary or higher education has remained unchanged over the past decade, while use among women with no education has increased to the same level. Martin has argued that once a country nears completion of its fertility transition, education does not play the same role as it did during the stage of high fertility. ${ }^{17}$ This shift seems to be occurring in Nepal.

However, education appears to be associated with the use of specific methods in Nepal. In 1996, there was no difference in the use of male and female sterilization across women's education levels, but there was a positive relationship between women's education and her use of hormonal methods, condoms and traditional methods. By 2006, a negative relationship was observed between higher levels of education and both types of sterilization, but there was no difference in hormonal method use across education levels. Studies in South Asia have found that uneducated women are more likely to use sterilization, as government programs promoting sterilization have often targeted rural women. ${ }^{21,23}$ The more recent availability of the injectable in Nepal has probably made hormonal methods more accessible to less educated women. In Kenya, commensurate with the overall rise in injectable 
use, higher levels of such use have been found among rural and uneducated women. ${ }^{35}$ Meanwhile, Kenyan husbands' education level continues to show a positive relationship with the use of male sterilization and condoms.

In the present study, wives' education levels were an important influence on the types of method used, but husbands' education levels were more influential in the use of male-controlled methods. These findings are consistent with previous results on the role of partners' education levels on contraceptive behavior. ${ }^{12,26,27,36}$ Furthermore, this study's results add to the growing literature by showing that the influence of wives' and husbands' education levels differed by partners' relative education level and the education gap between them. In the 2006 survey, female sterilization and hormonal methods were less likely to be used by couples in which both had secondary or higher education and by couples in which the education gap was minimal. Notably, these same couples had an elevated likelihood of using condoms. However, the likelihood of relying on male sterilization was highest not only among couples in which the husband had some secondary or higher education, but also among couples who had a large education gap.

This study has several limitations. Because it was based on cross-sectional data, the study could only identify associations between variables, not causality. In addition, although contraceptive choice was examined, it is important to recognize that some couples have very limited choice in the methods they adopt. Frequently, their choices are based on a programmatic focus that dictates what methods are available and accessible to specific segments of the Nepalese population.

\section{Conclusions}

The findings of this study have several important policy implications and suggest future research directions. Family planning programs need to consider the wife's educational status relative to that of her husband when trying to understand why specific methods are being used or not, especially at a time when education levels and contraceptive use are increasing. As the Nepalese population becomes more educated, there will likely be a greater demand for methods other than female sterilization and hormonal methods, and family planning programs should be prepared to meet this challenge. While this study shows that couples in which the husband is more educated are more likely to use male sterilization and condoms, future research should investigate whether this is because educated men are more involved in women's family planning decisions or because couples in which the husband is educated have greater purchasing power and greater access to methods. Future research should also place greater emphasis on the interaction of couples' education on their contraceptive method choice.

\section{REFERENCES}

1. Tuladhar JM, Emergence and development of Nepal's family planning program, in: Robinson WC and Ross JA, eds., The Global Family Planning Revolution: Three Decades of Population Policies and Programs,
Washington, DC: World Bank, 2007, pp. 363-375.

2. Nepal Ministry of Health and Population, New ERA and Macro International, Nepal Demographic and Health Survey, 2006, Kathmandu, Nepal: Ministry of Health and Population and New ERA; and Calverton, MD, USA: Macro International, 2007.

3. Schuler SR et al., Barriers to effective family planning in Nepal, Studies in Family Planning, 1985, 16(5):260-270

4. Schuler SR and Goldstein MC, Family planning in Nepal from the user's and nonuser's perspectives, Studies in Family Planning, 1986, $17(2): 66-77$.

5. Axinn WG, Family organization and fertility limitation in Nepal, Demography, 1992, 29(4):503-521.

6. Morgan PS and Niraula BB, Gender inequality and fertility in two Nepali villages, Population and Development Review, 1995, 21(3):541561.

7. Stash S, Explanations of unmet need for contraception in Chitwan, Nepal, Studies in Family Planning, 1999, 30(4):267-287.

8. Stash S, Son preference and the dynamics of fertility decisionmaking among wives and their husbands in rural Nepal, in: Sathar ZA and Phillips JF, eds., Fertility Transition in South Asia, New York: Oxford University Press, 2001, pp. 300-327.

9. Satyavada A and Adamchak DJ, Determinants of current use of contraception and children ever born in Nepal, Social Biology, 2000, 47(1-2):51-60

10. Chapagain M, Masculine interest behind high prevalence of female contraceptive methods in rural Nepal, Australian Journal of Rural Health, 2005, 13(1):35-42.

11. Chapagain M, Conjugal power relations and couple's participation in reproductive health decision-making: exploring the links in Nepal, Gender, Technology and Development, 2006, 10(2):159-189.

12. Gubhaju B, Understanding women's contraceptive decisionmaking dynamics in Nepal, unpublished dissertation, State College, PA, USA: Pennsylvania State University, 2006.

13. Dahal GP, Padmadas SS and Hinde PRA, Fertility-limiting behavior and contraceptive choice among men in Nepal, International Family Planning Perspectives, 2008, 34(1):6-14.

14. Cochrane SH, Fertility and Education: What Do We Really Know? Baltimore, MD, USA: Johns Hopkins University Press, 1979.

15. Mason KO, The impact of women's social position on fertility in developing countries, Sociological Forum, 1987, 2(4):718-745.

16. Jejeebhoy S, Women's Education, Autonomy and Reproductive Behavior, Oxford, UK: Clarendon Press, 1995.

17. Martin TC, Women's education and fertility: results from 26 Demographic and Health Surveys, Studies in Family Planning, 1995, 26(4):187-202

18. Moursund A and Kravdal O, Individual and community effects of women's education and autonomy on contraceptive use in India, Population Studies, 2003, 57(3):285-301.

19. Al Riyami AA, Mustafa A and Mabry RM, Women's autonomy, education and employment in Oman and their influence on contraceptive use, Reproductive Health Matters, 2004, 12(23):144-154.

20. Omariba D and Rasugu W, Women's educational attainment and intergenerational patterns of fertility behavior in Kenya, Journal of Biosocial Science, 2006, 38(4):449-479.

21. Khan MA and Rahman M, Determinants of contraceptive method choice in rural Bangladesh, Asia-Pacific Population Journal, 1997, 12(3):65-82.

22. Bulatao RA, Toward a framework for understanding contraceptive method choice, in: Bulatao RA, Palmore JA and Ward SE, eds., Choosing a Contraceptive: Method Choice in Asia and the United States, Boulder, CO, USA: Westview Press, 1989, pp. 277-304.

23. Mannan HR, Factors in contraceptive method choice in Bangladesh: goals, competence, evaluation and access, Contraception, $2002,65(5): 357-364$ 
24. Pal S and Makepeace G, Current contraceptive use in India: has the role of women's education been overemphasized? European Journal of Development Research, 2003, 15(1):146-169.

25. Dang A, Differentials in contraceptive use and method choice in Vietnam, International Family Planning Perspectives, 1995, 21(1):2-5.

26. Kulczycki A, The determinants of withdrawal use in Turkey: a husband's imposition or a woman's choice? Social Science \& Medicine, 2004, 59(5):1019-1033

27. Alpu $\mathrm{O}$ and Fidan $\mathrm{H}$, On the use of contraceptive methods among married women in Turkey, European Journal of Contraception $\mathcal{E}$ Reproductive Health Care, 2006, 11(3):228-236.

28. Koc I, Determinants of contraceptive use and method choice in Turkey, Journal of Biosocial Science, 2000, 32(3):329-342.

29. Dodoo FN, Men matter: additive and interactive gendered preferences and reproductive behavior in Kenya, Demography, 1998, 35(2): 229-242.

30. Becker S, Couples and reproductive health: a review of couple studies, Studies in Family Planning, 1996, 27(6):291-306.

31. Bankole A and Singh S, Couples' fertility and contraceptive decision-making in developing countries: hearing the man's voice, International Family Planning Perspectives, 1998, 24(1):15-24.

32. Pradhan A et al., Nepal Family Health Survey, 1996, Kathmandu, Nepal: Ministry of Health and New ERA; and Calverton, MD, USA: Macro International, 1997.

33. Nepal Ministry of Health, New ERA and ORC Macro, Nepal Demographic and Health Survey, 2001, Kathmandu, Nepal: Ministry of Health and New ERA; and Calverton, MD, USA: ORC Macro, 2002.

34. Jayaraman A, Mishra V and Arnold F, The relationship of family size and composition to fertility desires, contraceptive adoption and method choice in South Asia, International Perspectives on Sexual and Reproductive Health, 2009, 35(1):29-38.

35. Magadi MA and Curtis SL, Trends and determinants of contraceptive method choice in Kenya, Studies in Family Planning, 2003, 34(3):149-159.

36. Gereltuya A, Falkingham J and Brown J, Determinants of current contraceptive use and method choice in Mongolia, Journal of Biosocial Science, 2007, 39(6):801-817.

\section{RESUMEN}

Contexto: La asociación entre el nivel de educación y la fecundidad, el comportamiento anticonceptivo y la elección de método ha sido investigada extensivamente; sin embargo, poco se sabe acerca de la forma en que el diferencial educativo entre esposos y esposas en Nepal puede influir en la elección de métodos específicos.

Métodos: Se analizaron los datos obtenidos en las Encuestas de Demografía y Salud de Nepal de 1996, 2001 y 2006, sobre mujeres actualmente casadas y no embarazadas, en edades de 15-49 años, para identificar cambios en los niveles de educación de esposos y esposas y la influencia de esos cambios en el uso actual de métodos anticonceptivos por parte de las parejas durante la última década. Las asociaciones entre la elección de método y el nivel educativo de cada miembro de la pareja, el diferencial educativo entre miembros de la pareja y una medida combinada de educación, fueron evaluadas con modelos de regresión logística multinomial.

Resultados: Aunque el nivel de educación de la esposa estuvo asociado con el tipo de método usado por la pareja, el nivel de educación del esposo tuvo más influencia en el uso de la esterilización masculina y los condones. Por ejemplo, los hombres con alguna educación secundaria o superior tuvieron más probabilidad que aquellos sin escolaridad de recurrir a alguno de estos métodos (razones de riesgo relativo, 1.6-2.1). Además, las parejas en las que el esposo tenía al menos seis años más de educación que la esposa, también mostraron una mayor confianza en la esterilización masculina o los condones (1.6-1.8). Las diferencias en el uso de algún método de planificación familiar por nivel educativo se han reducido considerablemente en la última década, aunque aún sigue habiendo diferenciales en el uso de algunos métodos.

Conclusión: Se necesita una mejor comprensión de la forma en que los logros educativos relativos de las esposas y esposos afectan las decisiones sobre sus elecciones de anticonceptivos, especialmente en un momento en que tanto los niveles de educación como de uso de anticonceptivos están aumentando.

\section{RÉSUMÉ}

Contexte: L'association entre le niveau d'instruction et la fécondité, le comportement contraceptif et le choix de méthode a fait l'objet de bien des études. Le rôle de la différence d'éducation entre maris et femmes dans le choix de méthodes particulières au Népal n'est cependant guère documenté.

Méthodes: Les données collectées auprès des femmes mariées, non enceintes de 15 à 49 ans lors de l'Enquête démographique et de santé du Népal en 1996, 2001 et 2006 ont été analysées en vue d'identifier les différences entre les niveaux d'éducation des maris et des femmes et de déterminer, sur cette période de 10 ans, l'influence de ces différences sur la pratique contraceptive courante des couples. Des modèles de régression logistique multinomiale ont servi à évaluer les associations entre le choix de méthode et le niveau d'instruction de chaque partenaire, la différence d'éducation entre les partenaires et une mesure d'éducation combinée.

Résultats: Si le niveau d'éducation de la femme est associé au type de méthode utilisée par le couple, celui de l'homme influence davantage le recours à la stérilisation masculine et au préservatif. Ainsi, les hommes instruits au niveau secondaire ou supérieur sont plus susceptibles que ceux non instruits de recourir à l'une ou l'autre de ces deux méthodes (rapports de risques relatifs de 1,6-2,1). Qui plus est, dans les couples où le mari a au moins six années d'instruction de plus que la femme, le recours à la stérilisation masculine et au préservatif est également supérieur $(1,6-1,8)$. Les différences de pratique d'une méthode de planification familiale quelconque en fonction $\mathrm{du}$ niveau d'instruction se sont réduites considérablement ces 10 dernières années, bien que certaines différences persistent pour certaines méthodes.

Conclusion: À l'heure où les niveaux d'éducation et la pratique contraceptive sont tous deux en hausse, il importe de mieux comprendre l'effet du niveau d'instruction relatif des femmes et des maris sur les décisions relatives à leurs choix contraceptifs.

\section{Acknowledgments}

The author thanks Vinod Mishra, Sarah Bradley and Simona Bignami-Van Assche for helpful comments. This research was made possible by a fellowship from the U.S. Agency for International Development through the MEASURE DHS project at Macro International, Inc.

Author contact: b.gubhaju@unsw.edu.au 